\title{
Kendali Mode Luncur Pada Sistem Suspensi Aktif Dengan Simulasi MATLAB
}

\author{
Andi Pujo Rahadi \\ Program Studi Pendidikan Matematika, Universitas Advent Indonesia, Bandung \\ andi.rahadi@unai.edu
}

\begin{abstract}
Abstrak. Sistem suspensi mobil yang terdiri hanya dari pegas dan redaman merupakan sistem pasif sebab tidak menyediakan energi aktif untuk melawan gangguan profil jalan. Untuk mendapatkan kenyamanan dan keamanan berkendara yang lebih baik, ditanamkan sistem suspensi aktif pada mobil. Sistem suspensi aktif dilengkapi sensor dan komponen aktuator gaya yang menyediakan energi aktif dengan skema kendali tertentu. Penelitian ini bertujuan membangun sistem suspensi aktif menggunakan kendali mode luncur (sliding mode control / SMC). Simulasi sistem kendali dilakukan menggunakan MATLAB 2014, membandingkan performa sistem pasif, sistem aktif Linear Kuadratik (LQR), dengan sistem aktif Kendali Mode Luncur (SMC). Berdasarkan hasil simulasi, sistem aktif SMC mencapai kondisi stabil lebih cepat dan menggunakan gaya aktif lebih rendah. Dengan demikian, sistem SMC memiliki performa terbaik dibandingkan dengan dua sistem yang lain. Penelitian ini dapat dilanjutkan dengan membangun prototype suspensi dengan sistem kendali SMC.
\end{abstract}

Kata Kunci: Sistem Suspensi Aktif, Kendali Mode Luncur, Simulasi MATLAB.

\section{Pendahuluan}

Salah satu sistem yang ditanamkan pada setiap mobil adalah sistem suspensi pada masing-masing roda untuk menahan gangguan-gangguan vertikal yang sering terjadi pada saat mobil melaju di jalan raya seperti lonjakan, lubang, dan sebagainya. Sistem suspensi tersebut dirancang sedemikian rupa demi kenyamanan dan keamanan penumpang pada saat berkendara [1].

Sistem suspensi pasif memiliki dua komponen utama yaitu pegas dan redaman. Meskipun pegas dan redaman tersebut mampu memberikan kestabilan pada gerak vertikal mobil dalam batas tertentu, namun komponen-komponen tersebut tidak menyediakan energi pada sistem suspensi. Karena tidak menyediakan energi suspensi, maka sistem ini secara dinamik kurang responsif terhadap perubahanperubahan profil jalan [2].

Sistem suspensi aktif terdiri dari tiga komponen utama yaitu pegas, redaman, dan aktuator gaya. Aktuator gaya itulah yang dapat menyuplai energi pada sistem suspensi untuk menghasilkan suatu gerak relatif antara badan mobil dengan roda sedemikian hingga ketika terjadi perubahan profil jalan, sistem suspensi dapat mempertahankan kenyamanan dan keamanan berkendara [3].

Dalam naskah ini akan dibentuk model matematika untuk kedua sistem suspensi, yaitu pasif dan aktif, dalam bentuk ruang keadaan (state space). Selanjutnya akan ditentukan skema kendali mode luncur (sliding mode control - SMC - ) yang dikombinasikan dengan skema kendali linear kuadratik (linear quadratic regulator - LQR - ). Sebelum membangun model dan kendalinya, terlebih dahulu akan dibahas teori kestabilan sistem berdasarkan fungsi Lyapunov.

\subsection{Kestabilan Sistem}

Kestabilan sistem dalam naskah ini dibangun berdasarkan teorema 2.1 dan teorema 2.2.

Teorema 2.1 Diberikan sistem $\dot{x}=f(x), f\left(x^{*}\right)=0$ dengan $x^{*}$ merupakan titik interior dari $\Omega \subset$ $\mathbb{R}^{n}$. Diambil $V: \Omega \rightarrow \mathbb{R}$ fungsi yang kontinu dan differensiabel. Jika 
i. $\quad V\left(x^{*}\right)=0$,

ii. $\quad V(x)>0$, untuk semua $x \in \Omega, x \neq x^{*}$,

iii. $\quad \dot{V}(x) \leq 0$ di sepanjang semua trajektori sistem di dalam $\Omega$, maka $x^{*}$ bersifat stabil lokal,

selanjutnya bila (1),(2),(3) terpenuhi dan

iv. $\quad \dot{V}(x)<0$ untuk semua $x \in \Omega, x \neq x^{*}$ maka $x^{*}$ bersifat stabil lokal asimtotik.

Fungsi Vyang memenuhi (i) - (iv) disebut fungsi Lyapunov [3].

Teorema 2.2 Misalkan $M$ adalah matriks simetris yang definit positif atau semi definit positif dan $\left\{\lambda_{i}(M)\right\}$ adalah himpunan semua nilai eigen dari $M$, dalam hal ini

$V(x)=x^{\prime} M x$ memenuhi

1) $V(0)=0$, dan

2) $V(x)>0, \forall x \neq 0$.

Karena $M$ adalah matriks simetris dan mengingat $x^{\prime} M x=x^{\prime} \lambda x=\lambda\|x\|^{2}$ untuk setiap $\lambda \in\left\{\lambda_{i}(M)\right\}$ dengan x merupakan eigenvector yang terkait, maka berlaku [4]

$$
\lambda_{\min }(M)\|x\|^{2} \leq x^{\prime} M x \leq \lambda_{\max }(M)\|x\|^{2}, \forall x .
$$

\subsection{Pengaturan Linear Kuadratik}

Dalam subbab ini akan dibahas pengaturan kuadratik linear (linear quadratic regulator - LQR) untuk sistem yang kontinu terhadap variabel waktu [4]. Ditinjau plant linear varian-waktu yang disajikan pada Persamaan (1)

$$
\dot{x}(t)=A(t) x(t)+B(t) u(t)
$$

dengan $A(t)$ matriks keadaan berordo $n \times n, B(t)$ matriks masukan berordo $n \times r, x \in \mathbb{R}^{n}, u \in \mathbb{R}^{r}$ terkait dengan indeks performansi kuadratik

$$
J=\int_{0}^{\infty}\left(x^{\prime}(t) Q x(t)+u^{\prime}(t) R u(t)\right) d t
$$

dengan perilaku sistem diamati pada selang waktu $[0, \infty]$.

Secara ringkas, langkah-langkah desain LQR dapat dinyatakan sebagai berikut:

1) Mencari matriks definit positif $P$ yang memenuhi persamaan aljabar Riccati

$$
A^{\prime} P+P A-P B R^{-1} B^{\prime} P+Q=0 .
$$

2) Mencari matriks gain $K$ menurut persamaan

$$
K=R^{-1} B^{\prime} P .
$$

\subsection{Kendali Mode Luncur}

Dalam metode kendali mode luncur (sliding mode control) sebarang trajektori sistem akan dibawa menuju suatu permukaan luncur yang dipilih [5]. Permukaan luncur, disebut juga fungsi peralihan, merupakan sebuah pemetaan variabel-variabel gerak sistem ke suatu ruang vektor yang memiliki dimensi sama dengan dimensi vektor kendali sistem.

Untuk mendesain fungsi peralihan, ditinjau plant sistem

$$
\begin{gathered}
\dot{x}=f(x)+B(x) u(t), \\
x, f(x) \in \mathbb{R}^{n}, u \in \mathbb{R}^{m} B \in \mathbb{R}^{n \times m} .
\end{gathered}
$$

Akan didesain suatu kendali korektif $u_{c}(t)$ yang dapat mengantarkan sembarang keadaan sistem menuju suatu permukaan luncur (switching surface) tertentu. Vektor kendali tersebut memiliki bentuk umum [6] 


$$
\begin{gathered}
u_{c}(t)=\left[u_{i}(t, x)\right] \\
u_{i}(t, x)= \begin{cases}u_{i}^{+}(t, x), & \sigma_{i}>0 \\
u_{i}^{-}(t, x), & \sigma_{i}<0\end{cases}
\end{gathered}
$$

Permukaan switching yang dituju adalah

$$
\sigma(x)=\left[\begin{array}{lllll}
\sigma_{1}(x) & \sigma_{2}(x) & \ldots & \sigma_{m}(x)
\end{array}\right]^{\prime}=0
$$

Pada umumnya dipilih permukaan switching linear [7] yaitu

$$
\sigma(x)=S x, S \in \mathbb{R}^{m \times n} .
$$

Vektor kendali total untuk mode luncur selalu berbentuk:

$$
u=u_{c}+u_{e q},
$$

terdiri dari dua komponen :

1) Kendali korektif $u_{c}$, digunakan untuk memperkecil deviasi trajektori terhadap permukaan luncur sehingga pada akhirnya akan mengantarkan trajektori sistem dari sebarang keadaan menuju permukaan luncur yang dipilih,

2) Kendali ekuivalen $u_{e q}$, digunakan untuk membuat turunan permukaan luncur bernilai nol sehingga trajektori sistem akan tetap bertahan pada permukaan luncur yang telah dicapai.

Dalam bagian berikut ini akan dibahas kendali korektif untuk membawa trajektori sistem menuju suatu permukaan linear skalar.

State space sistem invarian dinyatakan sebagai

$$
\dot{x}=f(x)+B u(t), \quad x, u \in \mathbb{R}^{n}
$$

dengan permukaan peralihan dipilih:

$$
\sigma(x)=S x, \quad S \in \mathbb{R}^{m \times n} .
$$

Dalam hal ini, turunan dari fungsi Lyapunov V adalah

$$
\dot{V}=x^{\prime} S \frac{\partial \sigma(x)}{\partial x}[f(x, u)+B(x) u(t)] .
$$

Kendali korektif yang umum dipilih [8] berbentuk

$$
u_{c}(t)=-U(x) \operatorname{sign}(\sigma),
$$

dengan $\operatorname{sign}(\sigma)$ merupakan fungsi signum yaitu

$$
\begin{gathered}
\operatorname{sign}(\sigma)=\left[\operatorname{sign}\left(\sigma_{i}\right)\right] \\
\operatorname{sign}\left(\sigma_{i}\right)= \begin{cases}1, & \sigma_{i}>0 \\
-1, & \sigma_{i}<0\end{cases}
\end{gathered}
$$

Sedangkan kendali ekuivalen akan menghasilkan gerak yang menyinggung permukaan peralihan sebagai berikut

$$
\begin{gathered}
\frac{\partial \sigma(x)}{\partial x} \dot{x}=\frac{\partial \sigma(x)}{\partial x}\left[f(x, u)+B(x) u_{e q}(t)\right]=0 \\
\frac{\partial \sigma(x)}{\partial x} f(x, u)+\frac{\partial \sigma(x)}{\partial x} B(x) u_{e q}(t)=0 \\
\frac{\partial \sigma(x)}{\partial x} B(x) u_{e q}(t)=-\frac{\partial \sigma(x)}{\partial x} f(x, u) \\
u_{e q}(t)=-\left[\frac{\partial \sigma(x)}{\partial x} B(x)\right]^{-1} \frac{\partial \sigma(x)}{\partial x} f(x, u) .
\end{gathered}
$$


Selanjutnya dengan subtitusi $u_{e q}$ tersebut ke state space didapatkan dinamika ekuivalen sistem pada permukaan peralihan sebagai berikut

$$
\dot{x}=\left\{I-B(x)\left[\frac{\partial \sigma(x)}{\partial x} B(x)\right]^{-1} \frac{\partial \sigma(x)}{\partial x}\right\} f(x, u) .
$$

\section{Pembentukan Model Suspensi Dan Kendalinya}

Penelitian ini merupakan penelitian pengembangan sistem. Pertama-tama dibangun model matematika berdasarkan hukum-hukum gerak Newton, dilanjutkan dengan membangun sistem kendali SMC, kemudian dirancang simulasi sistem menggunakan Matlab 2014.

\subsection{Pemodelan Matematika Sistem Suspensi Aktif}

Ditinjau sistem suspensi aktif pada suatu model seperempat mobil

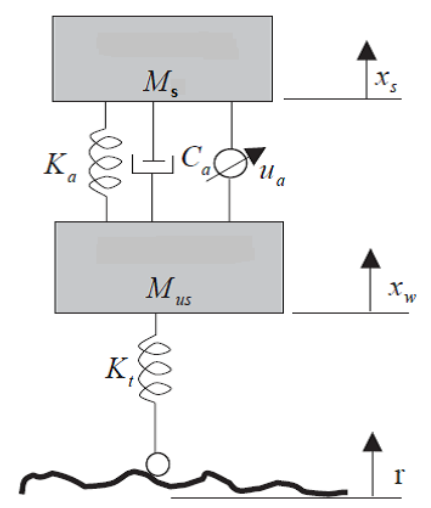

Gambar 1. Suspensi Aktif

Keterangan gambar 1 :

$M_{S}=$ massa badan mobil

$M_{u s}=$ massa roda mobil

$x_{s}=$ simpangan badan mobil

$x_{w}=$ simpangan roda mobil

$r=$ profil jalan

$K_{a}$ dan $K_{t}=$ tetapan pegas

$C_{a}=$ tetapan redaman

$u_{a}=$ aktuator gaya kendali.

Selanjutnya ditentukan variabel-variabel keadaan sebagai berikut

$$
\begin{aligned}
& x_{1}=x_{s}-x_{w}=\text { suspension travel } \\
& x_{2}=\dot{x_{s}}=\text { kecepatan badan mobil } \\
& x_{3}=x_{w}-r=\text { defleksi roda mobil } \\
& x_{4}=\dot{x_{w}}=\text { kecepatan roda mobil. }
\end{aligned}
$$

Persamaan state-space diturunkan berdasarkan hukum Newton yang diterapkan pada masing-masing massa. Ditinjau massa badan mobil [1]

Resultan gaya $=$ massa $\cdot$ percepatan 


$$
-\dot{x}_{2}=\left(\begin{array}{llll}
-\frac{K_{a}}{M_{S}} & -\frac{C_{a}}{M_{S}} & 0 & \frac{C_{a}}{M_{S}}
\end{array}\right)\left(\begin{array}{l}
x_{1} \\
x_{2} \\
x_{3} \\
x_{4}
\end{array}\right)+\left(\frac{1}{M_{S}}\right) u_{a} .
$$

Ditinjau massa roda mobil

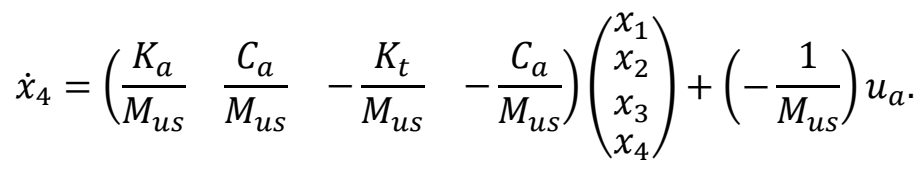

Selanjutnya $\dot{x}_{1}$ dan $\dot{x}_{3}$ ditentukan sebagai berikut

$$
\begin{aligned}
& \dot{x}_{1}=x_{2}-x_{4} \\
& \dot{x}_{3}=x_{4}-\dot{r}
\end{aligned}
$$

Dengan demikian diperoleh state space untuk sistem suspensi aktif yang disajikan pada Persamaan (2)

$$
\dot{x}(t)=A x(t)+B u(t)+f(t)
$$

dengan

$$
\begin{gathered}
\dot{x}(t)=\left(\begin{array}{l}
\dot{x}_{1} \\
\dot{x}_{2} \\
\dot{x}_{3} \\
\dot{x}_{4}
\end{array}\right), \quad x(t)=\left(\begin{array}{l}
x_{1} \\
x_{2} \\
x_{3} \\
x_{4}
\end{array}\right), \\
A=\left(\begin{array}{cccc}
0 & 1 & 0 & -1 \\
-K_{a} / M_{s} & -C_{a} / M_{s} & 0 & C_{a} / M_{s} \\
0 & 0 & 0 & 1 \\
K_{a} / M_{u s} & C_{a} / M_{u s} & -K_{t} / M_{u s} & -C_{a} / M_{u s}
\end{array}\right) \\
B=\left(\begin{array}{c}
0 \\
1 / M_{s} \\
0 \\
-1 / M_{u s}
\end{array}\right), u(t)=u_{a}, f(t)=\left(\begin{array}{c}
0 \\
0 \\
-1 \\
0
\end{array}\right) \dot{r},
\end{gathered}
$$

$x(t) \in \mathbb{R}^{n}$ adalah vektor keadaan,

$u(t) \in \mathbb{R}^{m}$ adalah input kendali,

Persamaan tersebut menunjukkan bahwa input gangguan tidak sefase dengan input aktuator, sehingga sistem mengalami keadaan mismatched . Dengan demikian, kendali yang diajukan haruslah cukup kuat untuk mengatasi keadaan mismatched tersebut [8]. Tujuannya adalah agar gangguan yang muncul tidak memberikan pengaruh signifikan terhadap performa sistem [9]. Untuk itulah naskah ini diajukan.

Pada sistem yang dibangun, diambil asums-asumsi berikut:

Asumsi 1. Terdapat konstanta positif $\beta$ sedemikian hingga $\|f(t)\| \leq \beta$, dengan $\|$.$\| adalah norma$ Euclidean standard.

Asumsi 2. Pasangan matriks $(A, B)$ dapat dikendalikan dan matriks input B memiliki rank penuh.

\subsection{Pembentukan Kendali Mode Luncur}

Dalam naskah ini digunakan permukaan luncur (sliding surface) integral proporsional [7] yang didefinisikan pada Persamaan (3)

$$
\sigma(t)=C x(t)-\int_{0}^{t}(C A-C B K) x(\tau) d \tau
$$


dengan $C \in \mathbb{R}^{m \times n}$ dan $K \in \mathbb{R}^{m \times n}$ adalah matriks konstan. Matriks $K$ haruslah memenuhi $\operatorname{Re}(\lambda(A-B K))<0$ dan matriks $C$ dipilih sedemikian hingga matriks $C B$ non-singular.

Diberikan persamaan ruang keadaan sistem suspensi aktif sesuai Persamaan (2)

$$
\dot{x}(t)=A x(t)+B u(t)+f(t)
$$

yang memenuhi Asumsi 1 dan Asumsi 2, berturut-turut adalah $\|f(t)\|<\beta$ dan pasangan matriks $(A, B)$ dapat dikendalikan. Gangguan profil jalan memiliki amplitudo yang berhingga dan dapat diukur sehingga dapat ditentukan nilai konstanta $\beta>0$ sebagai batas atas dari turunan profil jalan yaitu

$$
f(t)=\left(\begin{array}{c}
0 \\
0 \\
-1 \\
0
\end{array}\right) \dot{r}(t)<\beta
$$

Dalam bagian berikut akan disajikan lemma dan teorema mengenai sinyal kendali SMC yang diajukan terkait dengan ruang keadaan dan fungsi peralihan yang dipilih.

Lemma Diberikan matriks bernilai real $C=\left[\begin{array}{llll}c_{1} & c_{2} & c_{3} & c_{4}\end{array}\right]$ dengan $c_{1}, c_{2}, c_{3}, c_{4}>0, M_{s}$ dan $M_{u s}$ berturut-turut adalah massa badan mobil dan massa roda terkait Persamaan (3.3). Jika

$$
c_{4}=\left(1+\frac{c_{2}}{M_{s}}\right) M_{u s}
$$

Maka $1+C B=0$.

Bukti:

Dari anteseden lemma

Karena

$$
\begin{gathered}
c_{4}=\left(1+\frac{c_{2}}{M_{s}}\right) M_{u s} \\
\frac{c_{4}}{M_{u s}}=1+\frac{c_{2}}{M_{s}} \\
1+\frac{c_{2}}{M_{s}}-\frac{c_{4}}{M_{u s}}=0 .
\end{gathered}
$$

maka didapatkan $1+C B=0$.

$$
C B=\left(\begin{array}{c}
c_{1} \\
c_{2} \\
c_{3} \\
c_{4}
\end{array}\right)^{T}\left(\begin{array}{c}
0 \\
1 / M_{s} \\
0 \\
-1 / M_{u s}
\end{array}\right)=\frac{c_{2}}{M_{s}}-\frac{c_{4}}{M_{u s}}
$$

Teorema 3.1 Diberikan $k=\beta\|C\|+\mu$, dengan $\mu>0$. Untuk sistem di dalam Persamaan (2) dan fungsi peralihan menurut Persamaan (3) dibentuk

$$
\Omega=\left\{x(t):\|\sigma(t)\| \leq \frac{\beta\|C\|+\mu_{1}}{\mu-\mu_{1}} \delta\right\} .
$$

Dengan bilangan kecil $\delta>0$ dan $0<\mu_{1}<\mu$. Jika Sistem (3.3) diberi sinyal kendali

$$
u=(C B)^{-1}\left(K x-\frac{k \sigma}{\|\sigma\|+\delta}\right)=\left.(C B)^{-1}(K x-k \operatorname{sign}(\sigma))\right|_{\delta=0}
$$

Maka dalam waktu yang berhingga trajektori Sistem (2) akan tetap berada pada domain persekitaran permukaan luncur $\Omega$.. 
Bukti:

Diperhatikan Sistem (2)

$$
\dot{x}(t)=A x(t)+B u(t)+f(t)
$$

Dengan fungsi peralihan Persamaan (3)

$$
\sigma(x(t))=C x(t)-\int_{0}^{t}(C A-C B K) x(\tau) d \tau .
$$

Karena

(1) $\sigma^{2}=0$ untuk $\sigma=0$ dan

(2) $\sigma^{2}>0$ untuk $\sigma \neq 0$,

maka dipilih kandidat fungsi Lyapunov

$$
V(\sigma)=\sigma^{2} .
$$

Fungsi $V$ tersebut diturunkan terhadap waktu

$$
\begin{gathered}
\frac{d V(\sigma)}{d t}=\frac{\partial V(\sigma)}{\partial \sigma} \cdot \frac{\partial \sigma}{\partial t} \\
\dot{V}(\sigma)=2 \sigma \dot{\sigma}
\end{gathered}
$$

Dengan melakukan turunan terhadap waktu pada persamaan (3) diperoleh

$$
\dot{\sigma}(x(t))=C B u(t)+C f(t)+C B K x(t)
$$

Tanpa mengurangi makna variabel waktu $t$, persamaan tersebut dapat dituliskan

$$
\begin{gathered}
\dot{\sigma}=C B u+C f+C B K x \\
\dot{\sigma}=C B\left((C B)^{-1}(K x-k \operatorname{sign}(\sigma))\right)+C f+C B K x \\
\dot{\sigma}=K x-k \operatorname{sign}(\sigma)+C f+C B K x \\
\dot{\sigma}=(1+C B) K x+C f-k \operatorname{sign}(\sigma) .
\end{gathered}
$$

Dari lemma dapat dipilih $1+C B=0$ sehingga diperoleh

$$
\dot{\sigma}=C f-k \operatorname{sign}(\sigma)
$$

Didapat Persamaan (4)

$$
\dot{\sigma}=-c_{3} \dot{r}-\mu c_{3} \beta \operatorname{sign}(\sigma) .
$$

Nilai $\dot{V}$ akan dianalisis berdasarkan nilai $\sigma$ yaitu $\sigma>0$ dan $\sigma<0$.

(1) Untuk $\sigma>0$ didapatkan

$$
\operatorname{sign}(\sigma)=1
$$

Persamaan (4) menjadi

$$
\begin{aligned}
& \dot{\sigma}=-c_{3} \dot{r}-\mu c_{3} \beta \\
& \dot{\sigma}=-c_{3}(\dot{r}+\mu \beta) .
\end{aligned}
$$

Berdasarkan Asumsi 1,

$$
\begin{gathered}
\|f(t)\|<\beta \\
\|-\dot{r}\|<\beta \\
\|\dot{r}\|<\beta \\
-\beta<\dot{r}<\beta \\
0<\dot{r}+\beta<2 \beta .
\end{gathered}
$$


Karena $\mu>1$ maka

sehingga

$$
\dot{r}+\mu \beta>\dot{r}+\beta>0
$$

$$
\dot{\sigma}=-c_{3}(\dot{r}+\mu \beta)<0
$$

Jadi, untuk $\sigma>0$ berlaku

$$
\dot{V}(\sigma)=2 \sigma \dot{\sigma}<0 .
$$

(2) Untuk $\sigma<0$ didapatkan

$$
\operatorname{sign}(\sigma)=-1
$$

Persamaan (4) menjadi

Berdasarkan Asumsi 1,

$$
\begin{aligned}
& \dot{\sigma}=-c_{3} \dot{r}+\mu c_{3} \beta \\
& \dot{\sigma}=c_{3}(-\dot{r}+\mu \beta) .
\end{aligned}
$$

$$
\begin{gathered}
\|f(t)\|<\beta \\
\|-\dot{r}\|<\beta \\
\|\dot{r}\|<\beta \\
-\beta<\dot{r}<\beta \\
\beta>-\dot{r}>-\beta \\
\beta+\mu \beta>-\dot{r}+\mu \beta>-\beta+\mu \beta .
\end{gathered}
$$

Karena $\mu>1$ maka

$$
-\beta+\mu \beta>0
$$

Berakibat

$$
-\dot{r}+\mu \beta>-\beta+\mu \beta>0
$$

sehingga

Jadi, untuk $\sigma<0$ berlaku

$$
\dot{\sigma}=c_{3}(-\dot{r}+\mu \beta)>0
$$

$$
\dot{V}(\sigma)=2 \sigma \dot{\sigma}<0 .
$$

Berdasarkan (1) dan (2) berarti $\dot{V}<0$ untuk setiap $\sigma \in \Omega-\{0\}$.

Karena $\dot{V}(\sigma)<0$ untuk setiap $\sigma \in \Omega-\{0\}$, berdasarkan Teorema 2.2, maka $V(\sigma)$ adalah fungsi Lyapunov untuk setiap $\sigma \in \Omega$. Hal tersebut berarti dalam waktu yang berhingga, trajektori sistem akan terus-menerus berada di persekitaran permukaan luncur $\Omega$. Lebih jauh, untuk $\delta \rightarrow 0$ didapatkan $\Omega \rightarrow$ $\sigma=0$ yang artinya adalah jika $\delta=0$, pada suatu waktu yang berhingga trajektori akan mencapai permukaan luncur dan sesudah itu akan bertahan pada permukaan luncur tersebut [3]. Dengan kata lain, secara teoritis kendali yang diberikan berhasil menstabilkan sistem suspensi.

\section{Hasil dan Pembahasan}

Dalam bagian ini akan dilakukan simulasi terhadap tiga sistem suspensi yang telah dibangun pada bab 2 menggunakan MATLAB 2014. Simulasi komputer akan dilakukan dengan mengambil nilai-nilai numerik berikut:

$$
\begin{gathered}
M_{s}=290 \mathrm{~kg} \\
M_{u s}=59 \mathrm{~kg} \\
K_{a}=16812 \mathrm{~N} / \mathrm{m} \\
K_{t}=190000 \mathrm{~N} / \mathrm{m} \\
C_{a}=1000 \mathrm{Ns} / \mathrm{m} .
\end{gathered}
$$




\subsection{Sistem Pasif}

Untuk sistem suspensi pasif, state space yang akan disimulasikan sesuai dengan persamaan (1) yaitu

$$
\dot{x}(t)=A x(t)+f(t)
$$

Dengan

$$
\begin{gathered}
A=\left(\begin{array}{cccc}
0 & 1 & 0 & -1 \\
-K_{a} / M_{s} & -C_{a} / M_{s} & 0 & C_{a} / M_{s} \\
0 & 0 & 0 & 1 \\
K_{a} / M_{u s} & C_{a} / M_{u s} & -K_{t} / M_{u s} & -C_{a} / M_{u s}
\end{array}\right) \\
A=\left(\begin{array}{cccc}
0 & 1 & 0 & -1 \\
-58 & -3.4 & 0 & 3.4 \\
0 & 0 & 0 & 1 \\
284.9 & 16.9 & -3220.3 & -16.9
\end{array}\right) \\
\dot{r}(t)=\left\{\begin{array}{c}
\frac{a_{1}(1-\cos 8 \pi t)}{2}, \quad 0.50 \leq t \leq 0.75 \\
\frac{a_{2}(1-\cos 8 \pi t)}{2}, \quad 3.00 \leq t \leq 3.25 \\
0 \quad \begin{array}{c}
\text { untuk } t \text { yang lain } \\
a_{1} * 4 \pi \sin 8 \pi t, \text { untuk } 0.50 \leq t \leq 0.75 \\
0 \quad \text { untuk } 3.00 \leq t \leq 3.25,
\end{array}
\end{array}\right. \\
\left.\quad \begin{array}{c}
0 \\
0
\end{array}\right) \dot{r} \text { tuk } t \text { yang lain }
\end{gathered}
$$

\subsection{Sistem Aktif LQR}

State space sistem suspensi aktif dengan skema LQR sesuai dengan persamaan (2) yaitu

$$
\dot{x}(t)=A x(t)+B u(t)+f(t)
$$

Dengan parameter-parameter tersebut dalam bagian berikut akan diselidiki keterkendalian dari pasangan matriks $(A, B)$ tersebut.

$$
\begin{gathered}
A=\left(\begin{array}{cccc}
0 & 1 & 0 & -1 \\
-58 & -3.4 & 0 & 3.4 \\
0 & 0 & 0 & 1 \\
284.9 & 16.9 & -3220.3 & -16.9
\end{array}\right) \\
B=\left(\begin{array}{c}
0 \\
0.0034 \\
0 \\
-0.0169
\end{array}\right)
\end{gathered}
$$

Karena ruang keadaan dalam sistem tersebut berdimensi 4 maka dibentuk matriks keterkendalian

$$
\begin{aligned}
& C_{M}=\left[\begin{array}{lllllll}
B & \vdots & A B & \vdots & A^{2} B & \vdots & A^{3} B
\end{array}\right] \\
& C_{M}=\left[\begin{array}{cccc}
0 & 0.0204 & -0.4161 & -0.0531 \\
0.0034 & -0.0703 & 0.2522 & 0.2072 \\
0 & -0.0169 & 0.3457 & 0.0533 \\
-0.0169 & 0.3457 & 53.3425 & -2.1317
\end{array}\right]
\end{aligned}
$$

Karena rank dari $C_{M}$ tersebut adalah 4 maka pasangan matriks $(A, B)$ pada Persamaan (2) dapat dikendalikan. 
Matriks beban untuk indeks performansi $J=\int_{0}^{\infty}\left(x^{\prime} Q x+u^{\prime} R u\right) d t$, terkait kendali LQR dipilih sebagai berikut

$$
\begin{gathered}
Q=\left(\begin{array}{cccc}
10000 & 0 & 0 & 0 \\
0 & 10000 & 0 & 0 \\
0 & 0 & 10000 & 0 \\
0 & 0 & 0 & 10000
\end{array}\right) \\
R=0.0001
\end{gathered}
$$

Dengan menggunakan parameter state space dan matriks beban LQR, dibentuk program matlab terlampir. Dari program tersebut didapatkan matriks gain $K$ yaitu

$$
K=\left[\begin{array}{llll}
2750 & 9720 & -206400 & -8240
\end{array}\right]
$$

sedemikian hingga nilai eigen sistem loop tertutup skema LQR adalah

$$
\lambda(A-B K)=[-1.5168,-0.1987 \pm 0.1727 i,-0.0207] \text {. }
$$

Diperhatikan bahwa bagian real dari semua nilai eigen tersebut bernilai negatif yang secara teoritis menunjukkan bahwa setelah diberi kendali, sistem mencapai kestabilan.

Dengan demikian, sesudah diberi kendali state space lingkar tertutup sistem suspensi aktif LQR sesuai dengan Persamaan (2) yaitu

$$
\dot{x}(t)=\tilde{A} x(t)+f(t)
$$

dengan

$$
\tilde{A}=\left(\begin{array}{cccc}
0 & \tilde{A}=A-B K \\
-67.5 & 1 & 0 & -1 \\
0 & 0 & 711.8 & 31.8 \\
331.5 & 181.7 & -6718.8 & -156.5
\end{array}\right)
$$

\subsection{Sistem Aktif SMC}

Nilai-nilai parameter khusus yang terkait dengan simulasi sistem suspensi aktif dengan kendali mode luncur (SMC) adalah

$$
\begin{gathered}
C=\left[\begin{array}{lll}
c_{1} \quad c_{2} \quad c_{3} & c_{4}
\end{array}\right] \text { dengan } c_{1}=100, c_{2}=50, c_{3}=40, \\
c_{4}=4 *\left(1+\frac{c_{2}}{M s}\right) * \text { Mus } \\
\mu=1 \\
\beta=4 \pi * a_{1} \\
\|C\|=\sqrt{C C^{\prime}} \\
k=\beta\|C\|+\mu \\
\delta=0.001
\end{gathered}
$$

Permukaan luncur yang dituju adalah

$$
\sigma(x(t))=C x(t)-\int_{0}^{t}(C A-C B K) x(\tau) d \tau=0 .
$$

Sinyal kendali yang digunakan adalah

$$
u=(C B)^{-1}\left(K x-\frac{k \sigma}{\|\sigma\|+\delta}\right)
$$


Untuk melakukan simulasi sistem suspensi pasif dan aktif, kondisi awal yang dipilih adalah

$$
x(0)=\left(\begin{array}{l}
0 \\
0 \\
0 \\
0
\end{array}\right) .
$$

Seluruh file simulasi MATLAB tersebut disertakan dalam lampiran, sedangkan grafik hasil simulasi akan ditampilkan dan dianalisis dalam sub-bab 3.4.

\subsection{Respon Hasil Simulasi}

Grafik respon pergerakan suspensi, respon defleksi roda, dan respon percepatan terhadap waktu disajikan berturut-turut pada Gambar 1, 2, dan 3.

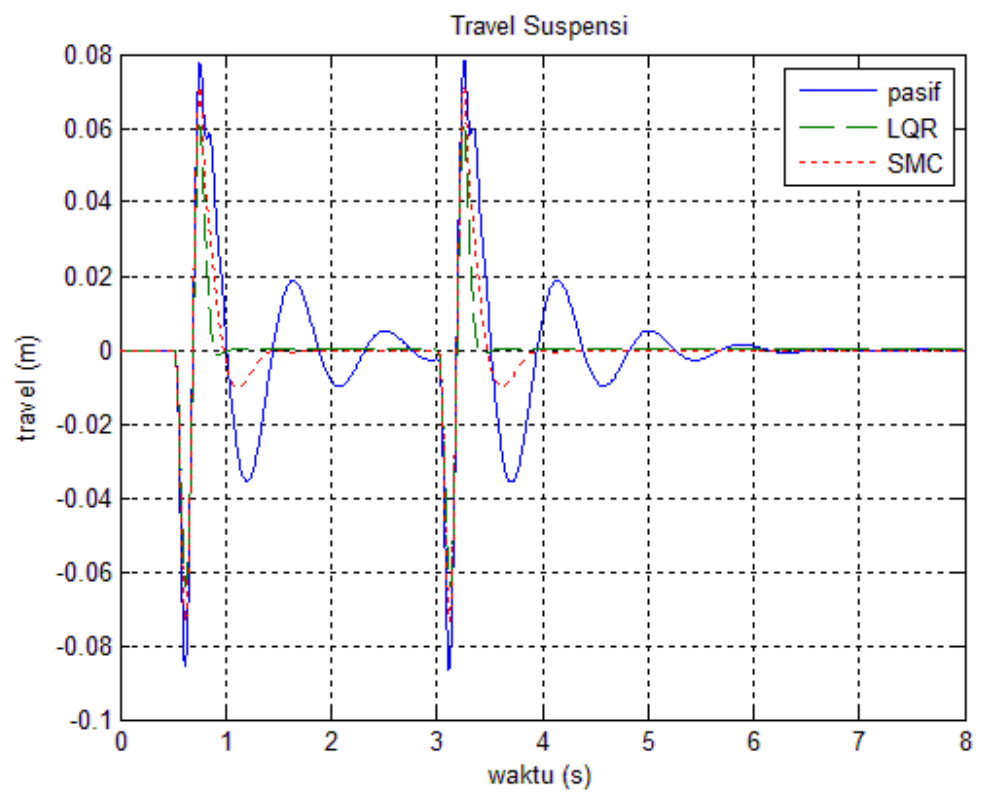

Gambar 1. Pergerakan (travel) suspensi untuk 3 sistem

Pada Gambar 1 disajikan respon sistem suspensi ketika diberi gangguan profil jalan berbentuk lonjakan pada detik ke 0,5 dan detik ke 3. Secara amplitudo grafik, ketiga skema memberikan hasil yang berbeda namun tidak terpaut jauh yaitu 0.0784 meter untuk sistem pasif, 0.0610 meter untuk sistem aktif LQR, dan 0.0713 meter untuk sistem aktif SMC. Pergerakan suspensi inilah yang dirasakan oleh penumpang.

Dari segi waktu nampak bahwa skema LQR dan skema SMC memberikan waktu mantap yang lebih singkat dibandingkan skema pasif. Sebagai contoh pada lonjakan pertama, sistem suspensi pasif tidak mampu menghentikan osilasinya sampai dengan detik ke 3 sedangkan sistem suspensi dengan skema LQR dan SMC berhasil menghentikan osilasi berturut-turut pada detik ke 1 dan detik ke 1,5. Dengan demikian dapat disimpulkan bahwa sistem suspensi yang diberi kendali mampu meniadakan pengaruh gangguan profil jalan dalam waktu yang lebih singkat dibandingkan sistem tanpa kendali.

Pada Gambar 2 disajikan respon simpangan atau defleksi roda mobil terhadap profil jalan. Hampir serupa dengan respon pergerakan suspensi, respon defleksi roda untuk sistem aktif memberikan waktu mantap yang lebih singkat dibandingkan dengan sistem pasif. Dari segi amplitudo defleksi nampak bahwa sistem aktif LQR memiliki amplitudo defleksi yang paling besar yaitu $4 \mathrm{~cm}, 4$ kali lebih besar dibandingkan dengan sistem pasif yang memiliki amplitudo defleksi $1 \mathrm{~cm}$. Defleksi roda yang terlalu besar memang tidak dirasakan oleh penumpang, namun hal tersebut mengakibatkan daya lekat roda terhadap jalan berkurang yang nantinya dapat mengurangi tingkat keamanan berkendara. Skema SMC menunjukkan performa yang lebih baik dibandingkan dengan skema LQR yaitu amplitudo defleksi roda $2,4 \mathrm{~cm}$ pada SMC dan $4 \mathrm{~cm}$ pada LQR dengan waktu mantap yang hampir sama dengan skema LQR 
murni. Dengan demikian sistem aktif dengan kendali SMC memiliki tingkat keamanan berkendara yang lebih baik dibandingkan dengan sistem aktif kendali LQR.

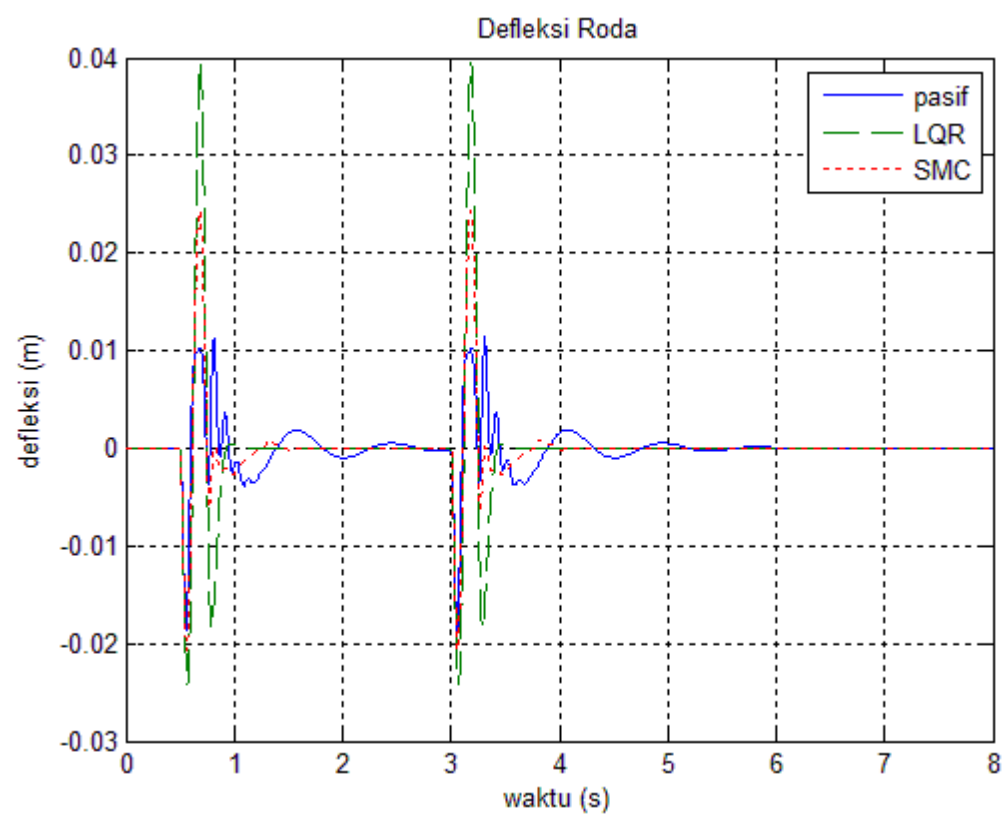

Gambar 2. Respon defleksi roda mobil

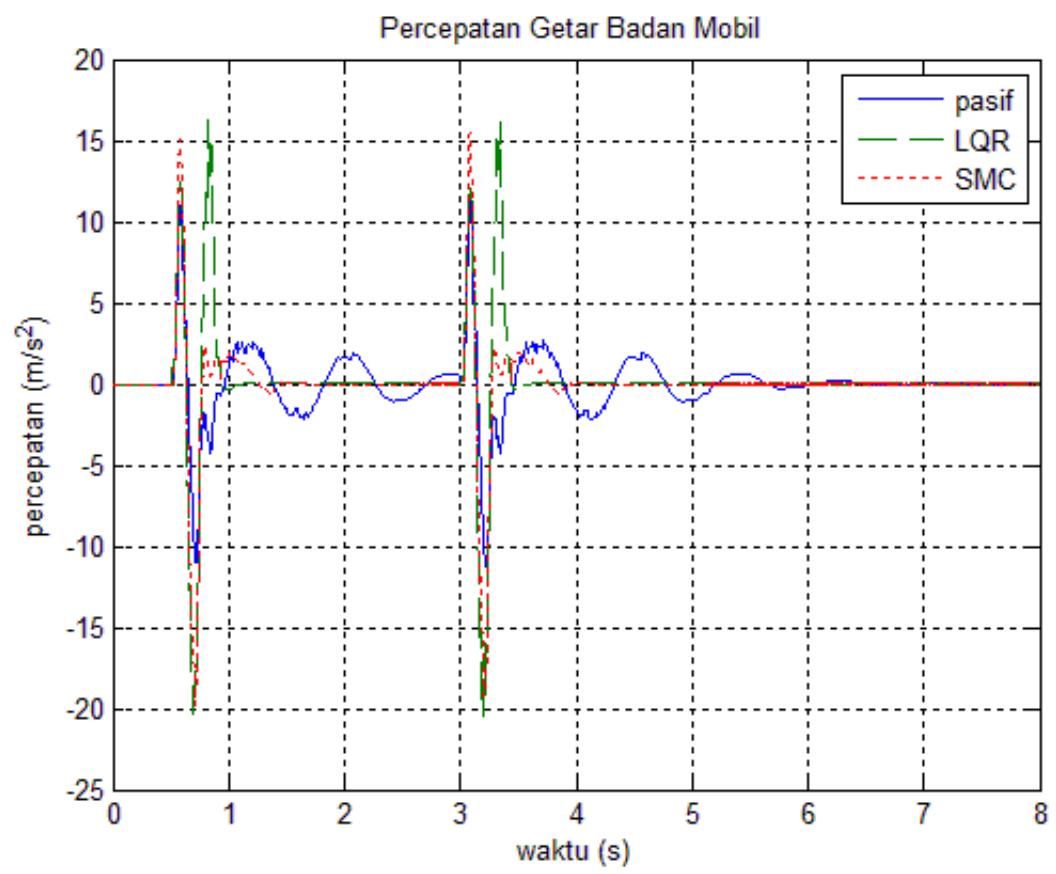

Gambar 3. Respon percepatan badan mobil

Nilai percepatan getar berbanding lurus dengan nilai resultan gaya yang bekerja pada badan mobil. Pada Gambar 3 disajikan respon percepatan getar badan mobil terhadap gangguan lonjakan yang diberikan dalam simulasi. Sebagaimana grafik respon pada Gambar 3.3 maupun Gambar 3.4, waktu mantap sistem aktif jauh lebih singkat dibandingkan sistem pasif. Bisa dikatakan penumpang akan lebih lama merasaksn gaya vertikal akibat gangguan lonjakan bila digunakan sistem suspensi pasif. Namun 
apabila sistem suspensi dilengkapi dengan aktuator gaya maka penumpang hanya merasakan gaya tidak lebih dari 0,5 detik saja. Dengan demikian mobil dengan sistem suspensi aktif terasa lebih nyaman dibandingkan dengan mobil dengan sistem suspensi konvensional (pasif).

Dari segi amplitudo percepatan dan banyaknya osilasi puncak, nampak bahwa sistem aktif dengan skema SMC masih lebih baik dibandingkan dengan sistem aktif dengan skema LQR. Amplitudo percepatan skema LQR adalah $0.0540 \mathrm{~m} / \mathrm{s}^{2}$ terjadi 2 kali dalam waktu 0,5 detik, sedangkan skema SMC memberikan amplitudo percepatan $0.0516 \mathrm{~m} / \mathrm{s}^{2}$ terjadi 1 kali dalam waktu yang sama. Banyaknya osilasi dan amplitudo percepatan tersebut akan mempengaruhi nilai energi yang dibutuhkan oleh aktuator dalam menjalankan fungsinya.

\section{Kesimpulan Dan Saran}

Dari hasil analisis yang telah diuraikan, dapat ditarik beberapa kesimpulan mengenai pengendalian sistem suspensi aktif menggunakan metode mode luncur di antaranya sebagai berikut:

1) Sistem suspensi yang diberi kendali (sistem aktif) mampu meniadakan pengaruh gangguan profil jalan dalam waktu yang lebih singkat dibandingkan sistem tanpa kendali (sistem pasif).

2) Skema SMC (Sliding Mode Control) menunjukkan performa yang lebih baik dibandingkan dengan skema LQR (Linear Quadratic Regulator), yaitu amplitudo defleksi roda 2,4 cm pada SMC dan $4 \mathrm{~cm}$ pada LQR. Dengan demikian sistem aktif dengan kendali SMC memiliki tingkat keamanan berkendara yang lebih baik dibandingkan dengan sistem aktif kendali LQR.

3) Mobil dengan sistem suspensi aktif terasa lebih nyaman dibandingkan dengan mobil dengan sistem suspensi konvensional (pasif).

4) Dari segi penggunaan energi, sistem suspensi aktif dengan kendali SMC lebih hemat energi dibandingkan dengan kendali LQR murni. Hal ini terindikasi dari respon percepatan sistem ketika diberi gangguan lonjakan di mana gaya vertikal yang dibangkitkan oleh skema kendali SMC lebih kecil dibandingkan dengan skema kendali LQR.

Untuk penelitian lebih lanjut, penggunaan metode kendali mode luncur sistem suspensi aktif ini dapat dikembangkan antara lain

1) Menghubungkan kendali ekuivalen SMC dengan skema kendali lain selain LQR sehingga diperoleh dinamika sistem yang lebih baik pada saat trajektori sistem telah berada di permukaan luncur,

2) Model kendaraan dikembangkan menjadi setengah kendaraan (2 roda) atau kendaraan penuh (4 roda) sehingga pengaruh gerakan horisontal dan lateral dapat dianalisis,

3) Merancang prototipe fisik sistem suspensi aktif dengan kendali mode luncur lengkap dengan sensor-sensornya sehingga dapat dilakukan simulasi secara nyata.

\section{Referensi}

[1] H. P. Wang, G. I. Y. Mustafa, and Y. Tian, "Model-free fractional-order sliding mode control for an active vehicle suspension system," Adv. Eng. Softw., vol. 115, pp. 452-461, Jan. 2018, doi: 10.1016/j.advengsoft.2017.11.001.

[2] M. I. Alfian and U. Wasiwitono, "Analisis Pengaruh Perubahan Geometri Suspensi terhadap Dinamika Getaran Sepeda Motor," J. Tek. ITS, vol. 7, no. 1, pp. E12-E16, Mar. 2018, doi: 10.12962/j23373539.v7i1.29898.

[3] H. K. Khalil, Nonlinear Systems. Prentice Hall, 2002.

[4] Katsuhiko Ogata, Modern Control Engineering, 5th ed. Prentice Hall, 2009.

[5] V. I. Utkin, Sliding Modes in Control and Optimization (Communications and Control Engineering), 1st ed. Heidelberg: Springer-Verlag, 1992.

[6] C. Edwards and S. Spurgeon, Sliding mode control: theory and applications. Florida, USA: Taylor \& Francis Group, 1998.

[7] V. Utkin, J. Guldner, and M. Shijun, "Sliding mode control in electro-mechanical systems," CRC Press, vol. 34, 1999. 
[8] S. A. Chen, J. C. Wang, M. Yao, and Y. B. Kim, "Improved optimal sliding mode control for a non-linear vehicle active suspension system," J. Sound Vib., vol. 395, pp. 1-25, May 2017, doi: 10.1016/j.jsv.2017.02.017.

[9] B. Lin, X. Su, and X. Li, "Fuzzy Sliding Mode Control for Active Suspension System with Proportional Differential Sliding Mode Observer," Asian J. Control, vol. 21, no. 1, pp. 264-276, Jan. 2019, doi: 10.1002/asjc. 1882 . 